\title{
LITERATURA Y MÚSICA
}

Esther López Ojeda

I.E.S. Escultor Daniel

RESUMEN: La música ha sido la coartada de la literatura desde la Antigüedad hasta nuestros días. Incluso las dos artes confluyen en composiciones con gran significación: dramas musicales, óperas, etc. Cada movimiento estético se ha cuestionado la relación que se establece entre la música y la literatura, aportando su propio significado. En las composiciones se pueden establecer relaciones de complementariedad entre las dos artes, de intertextualidad con códigos que se entrecruzan, cada una de las artes puede ser evocada por la otra, etc.

Palabras clave: Música, literatura, relaciones música-literatura, análisis comparativo, intertextualidad.

\section{LITERATURE AND MUSIC}

ABSTRACT: Music has been an excuse for literature from the Antiquity to our days. Even both arts come together in compositions with great significance: musical dramas, operas, etc. Every aesthetic movement has questioned the relation established between music and literature, contributing his own meaning. In the compositions relations of complementarity can be established between both arts, intertextuality with codes that interwave, each of the arts can be evoked by the other one, etc.

Keywords: Music, literature, music-literature connections, comparative analysis, intertextuality.

La multiplicidad de códigos y de subcódigos que se entrecruzan en una cultura nos demuestran que incluso el mismo mensaje se puede descodificar desde distintos puntos de vista y recurriendo a diversos sistemas y convenciones.

U. Eco, La estructura ausente 


\section{Códigos que se entrecruzan. De la música a la literatura y de la literatura a la música}

Múltiples códigos se entrecruzan en las manifestaciones musicales y literarias, relacionadas y frecuentemente permeables entre sí, hasta el punto de creaciones en las que, por la evolución propia de la cultura, influyen las unas en las otras desdibujando la frontera entre ambas. Incluso las obras musicales y literarias pueden confluir en productos culturales de mayor significación (dramas musicales, óperas, etc.), en los que la parte musical y la literaria forman dos niveles de un mismo discurso.

La literatura utiliza la música como coartada: el texto de las canciones necesita de ella, la lírica comparte con la música uno de sus elementos esenciales como es el ritmo, en el género dramático la presencia de la música es constante (para crear la ambientación, la caracterización de personajes, señalar las partes de la acción...), el texto literario reflexiona sobre la música y la teoría musical, etc. Además, la música también utiliza a la literatura como coartada: los textos muchas veces son musicalizados, hay correspondencia entre la frase melódica y la frase textual, la música programática evoca lo extramusical acercándose a la narración literaria, la literatura es fuente de inspiración de temas, personajes y formas para la música, etc.

Las características estéticas y culturales de cada época conforman la creación artística, marcando así la influencia mutua que se produce entre música y literatura. Es evidente, por otra parte, que la transferencia de rasgos entre las distintas manifestaciones artísticas es algo habitual, por lo que la relación entre música y literatura se inserta en un fenómeno más amplio (en el que podríamos encontrar, por ejemplo, la influencia de los colores en Scriabin, de la pintura de las vanguardias históricas del s. XX en todas las artes, etc.).

Los códigos musicales y literarios interaccionan entre sí y se retroalimentan mutuamente, enriqueciendo los discursos con su plurisignificación, desde una relación de complementariedad hasta la imitación de procesos literarios y sonoros o la utilización de analogías: coincidencias entre la retórica musical y literaria, citas entre los dos discursos, evocaciones...

Partimos de la base de que las relaciones entre significante y significado del texto literario se pueden encontrar también en la obra musical, a pesar de que esta es más compleja y ha suscitado ríos de tinta sobre en qué sentido podemos hablar de significado. Adorno en el s. XX señalaba cómo la música tiene muchas concomitancias con el lenguaje pero la separa de él el hecho de que le es imposible comunicar un significado unívoco, no tiene referencia a un ámbito de conceptos, estrictamente [2000: 27]. Aun así, recordemos en este punto que incluso la estética musical formalista, representada con la teoría de Hanslick, reconoció esa dualidad en la música, aunque circunscribiendo el contenido a las ideas puramente musicales que una obra transmite. Por ello, esta coincidencia en los elementos constitutivos nos ofrece la posibilidad de acer- 
carnos a las relaciones entre música y literatura atendiendo al plano formal y al semántico. Desde el punto de vista literario el texto se relacionará con la música en cualquier nivel (fónico, morfosintáctico y semántico).

La música es un fenómeno de duración en el tiempo, semejante a la literatura oral o a las representaciones teatrales, que se realiza en el presente y que cobra sentido en la conciencia del receptor. La comunicación entre emisor y receptor no es directa, a no ser para una minoría que lee partituras musicales, sino que se lleva a cabo a través de la reinterpretación de quienes ejecutan la obra. En la audición musical no hay opciones para la pausa voluntaria o para "releer" algo ya pasado, por lo que la percepción del oyente se acentúa mucho más que en la literatura donde, excepto en su manifestación oral, se tiene la oportunidad de desandar los pasos. Sin embargo, tanto en música como en literatura, simplemente porque ambas son arte, entra en juego la experiencia estética del receptor: el factor cultural y educativo, el imaginativo, el factor emocional o afectivo, todo ello reorganizado y re-experimentado en la recepción de la obra. Y son muchas más las coincidencias entre ambas, ya que estamos ante sendos sistemas de comunicación mediante signos, lo que nos facilita establecer sus relaciones. En este sentido comparten las funciones de la Teoría de la Comunicación atribuidas por Jakobson al texto [1981: 352-360]: referencial, apelativa, expresiva, fática, poética y metalingüística (o "metamusical", en nuestro caso). La música puede suscitar una atmósfera sonora, un clima emocional, recrear una realidad subjetiva e interior (emociones, sensaciones o estados de ánimo), así como referirse a un paisaje, ubicar los hechos (en una época, país o región, naturaleza o interiores), etc.; un tempo o ritmo acelerado denotará un objeto o sujeto en movimiento; la agitación se puede expresar con staccatos, vibraciones, trémolos, aceleraciones y crescendos rápidos, cambios de tono, fortísimos, etc. Múltiples signos para expresar lo que también puede hacerse a través del lenguaje literario. Ambas pueden crear centros de atención (la tonalidad en música o el tema en literatura), suscitar expectativas en el receptor sobre el desarrollo posterior (resolución de los acordes o argumentos literarios), tienen un ritmo, utilizan repeticiones (en música con mayor necesidad psicológica para que sean captadas por el receptor), comparten texturas y estructuras con desarrollo, clímax, etc. Además de estos códigos compartidos, la música sigue siendo una coartada para la literatura, y viceversa.

\section{Las relaciones música-literatura como una constante en la cultura occidental}

Detenernos en ellas es descubrir la relevancia del vínculo entre las dos artes, la importancia de la propia relación en la creación y desarrollo tanto de las manifestaciones artísticas musicales, por un lado, como de las literarias, por otro. Sin referirnos en este momento a la manera en que se conjugan la música y la literatura, el propio hecho de que son dos artes que constantemente confluyen condiciona las composiciones en todos los movimientos estéticos. Como 
si el intentar resolver cómo conjugar la música y el texto fuera una eterna pregunta, todas las épocas tratan de contestarla y vuelve a aparecer cada vez que se produce un cambio de estética. Creemos que esto no es una cuestión trivial, aunque permanece en la sombra en los estudios teóricos que suelen abordar las artes por separado, sino que condiciona las creaciones de cada época, los discursos teóricos, las expectativas del receptor e incluso la ejecución musical.

La relación entre música y literatura es una constante en las manifestaciones artísticas occidentales, con testimonios claros desde Grecia, donde ya encontramos un concepto de música y literatura bien documentados, hasta nuestros días. No entendemos la Historia de la Música y la Historia de la Literatura como el desarrollo de un arte cada vez más perfecto que culmina en la actualidad, sino que los conceptos van variando sin que tiendan a una elaboración mayor. Sí que se establece, por otro lado, una relación dialéctica entre la teoría y la práctica, que aunque no es el objeto de estudio que nos ocupa está en el trasfondo de lo estudiado: una vez establecidas en un período las normas de composición y escritura, estas pasan a la teoría musical o literaria y desde la posición teórica vuelven a influir en compositores o escritores, bien para aprovechar sus posibilidades en el proceso creativo o bien para introducir variantes si consideran que han Ilegado al agotamiento expresivo; y el proceso se vuelve a repetir en el siguiente período. Este es el proceso habitual, a lo largo de los siglos y de los movimientos artísticos, aunque un par de excepciones, en las que la teorización se ha adelantado a la práctica, nos parecen singulares: la época griega, donde conceptos como la comprensión del cosmos a través de las relaciones matemáticas, el ethos o la catarsis influyeron en el desarrollo musical y literario, y no al revés, aunque cuando la práctica está establecida repercute en la teoría; y otro momento, el s. XVII, cuando se recupera en los tratados teóricos la monodia griega en favor de la comprensión del texto y de ahí deriva su práctica. También podríamos hacer referencia aquí a las vanguardias del s. XX, que dan paso a la creación musical y literaria después de la publicación de su estética en manifiestos, aunque tuvieron un desarrollo temporal muy rápido donde teoría y práctica se superponen.

Veamos el ejemplo del s. XVII que hemos mencionado. Se inició musicalmente con una serie de polémicas que se difundirán también durante el s. XVIII, las que se establecen entre lo antiguo (primera práctica) y lo nuevo (segunda práctica), entre la convención y la innovación. La polémica entre Artusi y Monteverdi nos ilustra el paso de una concepción anclada en la vieja práctica del estilo contrapuntístico o polifónico frente a las novedades del nuevo estilo con la monodia acompañada de acordes. Italia va a ser un hervidero de polémicas que se extenderán durante el Barroco, el Preclasicismo y el Clasicismo a otras áreas geográficas: en Francia la querelle des Bouffons, en España la polémica en torno a la misa Scala Aretina de F. Valls, etc.

Numerosas diatribas suscitadas a lo largo de los s. XVII y XVIII tienen como telón de fondo el problema de la relación música-texto. Cuestiones en torno a 
la autonomía de la música respecto a la poesía y a si la música siempre ha de servir al texto, etc. son las que van emergiendo en los teóricos de la época. Tanto el concepto de arte -se condena el arte por el arte-, como el concepto de música -arte dirigido a los sentidos y no a la razón- están impregnados por la filosofía cartesiana. En la jerarquización de las artes la música ocupaba el último lugar y la poesía el primero. La música, al dirigirse al sentido del oído, fue considerada una manera inferior de captar, comprender y reconocer la realidad, la verdad. Pero la poesía mediante las palabras se dirige a la razón y tiene una potencialidad didáctico-conceptual que no tiene la música. En el nuevo estilo, el texto es quien domina sobre la música.

Los músicos, poetas y teóricos crearon en Florencia la Camerata Florentina o Camerata Bardi. Se conocían los estudios de G. Mei que defendía que los griegos obtenían efectos con su música debido a que esta tenía una sola melodía. V. Galilei, seguidor de Mei, publicó Dialogo della musica antica y della moderna (1581): atacó el contrapunto vocal, argumentando que si varias voces simultáneamente cantaban diferentes melodías y palabras en ritmos y registros diferentes, la música no podía plasmar el mensaje emocional del texto. Defiende que la manera correcta de musicalizar las palabras es con la melodía solística que realza las inflexiones naturales del habla. G. Caccini y J. Peri buscaron una fórmula entre el recitado hablado y el canto. Con sus óperas el recitativo se consolidó y el bajo continuo hizo su primera aparición. La Camerata Florentina defendió la monodia acompañada, canto solista con melodía y acompañamiento de acordes pensados "armónicamente" ${ }^{\prime}$. Criticaban la práctica polifónica por considerarla inadecuada y pedante para expresar el contenido de los textos, siguiendo la moderna teoría de los afectos. El hecho de que cada voz interpretara una palabra diferente entorpecía la comprensión. Así, en el nacimiento de la monodia la teoría precede a la práctica. Se tomó como modelo la monodia antigua griega, aunque no se conocía directamente, pero sí sus efectos sobre los receptores.

A finales del s. XVI en Italia se dotó a las obras de una violencia y una intensidad sin precedentes. Los textos, emocionalmente intensos, requerían medios musicales infrecuentes que perturbaban el equilibrio de la polifonía renacentista. Utilizaron tritonos, séptimas, novenas, tesituras extremas, silencios bruscos, cambios de tempo y texturas de acordes con ocasionales disonancias, cromatismos o pasajes contrapuntísticos que culminarán en la segunda práctica que Monteverdi proclama en el cambio de siglo.

El virtuosismo vocal, la libertad rítmica y el poder emotivo de la música íntimamente relacionado con el contenido del texto eran las características de la

1. Aunque no puede hablarse aún de tonalidad establecida, puesto que las obras no tienen dirección tonal. Sin embargo, tampoco el acompañamiento es modal ni polifónico, sino acórdico con voluntad armónica. 
melodía, la cual podía presentarse de dos maneras: una melodía parecida a la canción, con una línea de bajo más animada; o una apariencia de recitativo con bajo estático, que da origen al "estilo representativo" que es el germen de la ópera. En la práctica, se superaron estas restricciones expresadas teóricamente. El melodrama, la ópera, a pesar de las muchas críticas que recibió, acabó imponiéndose. Lo mismo ocurrió con las innovaciones armónicas que subrayaban parte de los textos que servían de soporte.

Francesc Valls en su tratado musical Mapa Armónico (1742) hace referencia a los recursos para adecuar perfectamente la música al contenido del texto. El contenido semántico del texto poético es para F. Valls:

"la materia más importante para el buen compositor, pues sin ella será como un pintor que sabe bien dibujar, pero ignora el arte de aplicar los colores a la imagen, importa poco que el músico sepa todas las habilidades, que hasta aquí se han manifestado, si no sabe él cómo vestir la letra que tiene a su cargo. [...] Consiste esta gran circunstancia, en entender bien el sentido de la letra, así de latín como de romance, no en lo material de las palabras, sino en lo formal del concepto, pues quien esté atado a lo material de ellas, hará tantos yerros, cuantas fueren las sílabas". [...] [EI cambio de modo es] aptísimo para expresar afectos opuestos, como tristeza y alegría, temor y valor. [...] Cuando se cante, toda la que fuere dolorosa, triste o lúgubre, la rija muy despacio si es alegre o festiva, vaya el compás aprisa, pero no tanto que no se perciba la letra. En toda composición que fuere lúgubre y triste será muy del caso cuando la letra lo permita que callen todas las voces e instrumentos aguardando alguna pausa porque con esta suspensión se concilia la atención del auditorio y se expresa más el afecto." [León Tello, 1973: 570-571].

La teoría musical también se encargó de determinar la relación diferenciada de cada elemento musical técnico-formal con los afectos. La expresión de las pasiones y los movimientos del alma preocupó a todas las artes. La música se relacionó con la retórica y al igual que esta intentó convencer mediante la emoción y la razón. Incluso se establecieron analogías entre figuras retóricas y motivos musicales (antítesis: contraste u oposición de melodía, matiz o efecto; exclamatio: salto de sexta ascendente; anadiplosis: repetición de una melodía con carácter concluyente al principio de una nueva parte o sección; apócope: imitación fugada en la que la repetición del sujeto es incompleta en una de las partes; etc.).

Además de estos aspectos teóricos, cuando adoptamos un punto de vista diacrónico sobre las relaciones entre música y literatura descubrimos la tendencia a expresar un arte cada vez más personal. En este sentido encontramos en las composiciones musicales y literarias un proceso: desde la explicación a través de la música y la literatura del mundo exterior hasta convertirse en representantes de la expresión más personal. Proceso especialmente acentuado desde la inflexión que supone el s. XIX, donde se introduce cada vez más lo 
subjetivo e incluso se apela al propio espectador, algo novedoso, para que intervenga activamente en el cierre de la obra.

Apoyamos esta teoría en ejemplos tan claros como la comparación que podemos establecer entre el proceso compositivo de la música aleatoria, de los años 50 del s. XX, y novelas como Rayuela, de Julio Cortázar (1963), que responden a una misma intención creativa. La música aleatoria, a grandes rasgos, introduce el azar en la determinación de su estructura. En cuanto a la interpretación, otorga gran libertad a cada instrumentista y, en cuanto a la composición, se caracteriza por la indicación en la partitura de las diversas alternativas que podrán seguirse en el momento en que se ejecute. Se distingue del indeterminismo: en este la libertad del intérprete es completa y aparece reflejada en la partitura de diversas maneras. El compositor puede servirse de una notación indeterminada (por ejemplo, clusters de extensión imprecisa) o llegar a crear una nueva notación que obliga al intérprete a descifrarla. Con el estreno de Klavierstück XI de Stockhausen y la Tercera sonata para piano de Boulez, el azar entró definitivamente en el vocabulario vanguardista. La obra de Stockhausen se inicia con una hoja que contiene diecinueve fragmentos de música, que pueden ser ejecutados en cualquier orden. Después de tocar uno, el pianista debe girar la página para buscar otro, tocándolo según los parámetros dados al final de la última. Un fragmento se puede repetir, pero la pieza acaba cuando se repita por tercera vez cualquier fragmento. En la obra de Boulez las posibilidades son más limitadas, reduciendo el número de variaciones en que se puede leer la obra.

Esta técnica compositiva, ¿no recuerda al código de lectura de Rayuela de J. Cortázar? Incluso las páginas de la novela tienen una numeración especial marcando constantemente, además de la paginación habitual, el capítulo al que pertenecen, lo mismo que las partituras de la música aleatoria o indeterminada. Cortázar desarrolla el concepto que expuso Borges en El libro de arena, donde indicaba que el número de las páginas del libro era infinito: ninguna era la primera y ninguna era la última. Veamos el fragmento de Rayuela [1993: 5]:

\section{TABLERO DE DIRECCIÓN}

A su manera este libro es muchos libros, pero sobre todo es dos libros. El lector queda invitado a elegir una de las dos posibilidades siguientes:

El primer libro se deja leer en la forma corriente, y termina en el capítulo 56, al pie del cual hay tres vistosas estrellitas que equivalen a la palabra Fin. Por consiguiente, el lector prescindirá sin remordimientos de lo que sigue.

El segundo libro se deja leer empezando por el capítulo 73 y siguiendo luego en el orden que se indica al pie de cada capítulo. En caso de confusión u olvido, bastará consultar la lista siguiente: 73 - 1 - 2 - 116 - 3 - 84 $4-71-5-81[\ldots]$ 
Con objeto de facilitar la rápida ubicación de los capítulos, la numeración se va repitiendo en lo alto de las páginas correspondientes a cada uno de ellos.

Los ejemplos de apertura formal son numerosos en esta época puesto que responden a una misma estética que se plasma con dos artes diferentes, como descubrimos en los siguientes ejemplos. En el estilo musical de J. Cage encontramos semejanzas con la literatura de J. Joyce. L. Berio, con la música electrónica, trabajó con el mismo escritor para hacer transformaciones en el texto de Ulises para crear su Homenaje a Joyce. La nueva concepción de K. Penderecki, creando texturas sin predominio de la melodía, la armonía y el ritmo y sin diferenciar entre ruido y sonido, se asemeja a La saga/fuga de J. B., de G. Torrente Ballester, que rompe con el desarrollo cronológico, mostrándolo de forma caótica y fragmentaria, con una estructura desorganizada, personajes equívocos con desdoblamientos de personalidad y metamorfosis en seres diversos, mezclando elementos mágicos y reales y con una ironía muy particular. Así como Penderecki hace referencias a Bach o Stravinsky, Torrente Ballester las hace a la historia española, la explotación turística de los mitos religiosos (el Cuerpo Santo), la represión sexual y hasta el estructuralismo lingüístico, entre otras. Incluso la escritura de la novela rompe con el modelo tradicional, como la partitura musical, e incluye tablas, gráficos, listados, etc.

La aproximación a las relaciones entre música y literatura también descubre que disciplinas habitualmente aplicadas al texto, como la Retórica o la Semiótica, pueden encontrarse en el vínculo entre texto y música. Quizá, de las dos, la más sorprendente sea la Retórica, que se retoma en el Barroco como una disciplina que proporciona claves para la transmisión de afectos, uno de los pilares importantes de la época, tanto a través del texto como a través de la música. No sólo se recogen las pautas retóricas en el momento creativo (inventio, dispositio, elocutio), sino también figuras retóricas concretas que afectan a la melodía o a la línea argumental (anáfora, distributio recapitulativa...), a la armonía o al desarrollo temporal del texto (anticipatio, suspensión...), o a varios elementos (por adición, sustitución...), lo que se aplica tanto a la parte musical como a la literaria. El acercamiento de la Semiótica a las manifestaciones artísticas en las que confluye texto y música es más evidente ya que se centra en el estudio de los códigos, de gran riqueza debido a que hablamos de composiciones en las que se han unido las dos artes. Y, junto a ellas, tenemos que hacer una mención a la Semántica, tan debatida desde el punto de vista musical, y que establece vinculaciones especiales entre el texto y la música. Ya conocemos, en este sentido, el leitmotiv wagneriano, buen ejemplo de lo que estamos hablando: motivo musical que se relaciona con aspectos del drama y que, desde el sonido, conduce al oyente en la comprensión de la trama literaria. Así se le otorgan a la música significados especiales que, en principio, no le son propios, y se esta- 
blece una relación de analogía entre el texto y la música. Otro ejemplo significativo sería la música programática.

\subsection{Algunos ejemplos a lo largo de la historia}

La composición de textos para ser cantados con acompañamiento musical es un hecho intrínseco al ser humano. Desde la Antigüedad clásica hasta nuestros días, teóricos y músicos han cuestionado las relaciones que se establecen entre la música y el texto y se han decantado por la primacía de una u otro en cada época, dando respuesta así, a través del vínculo entre las dos artes, a los rasgos estéticos y culturales del momento. Los testimonios literarios de la Antigüedad muestran la coartada de la música. Obras como la Ilíada y la Odisea recogen en el léxico referencias al acompañamiento musical del texto. "Canta, oh diosa, la cólera funesta del Pélida Aquiles", es el testimonio del primer verso de la llíada, que convierte toda la obra en un canto [2006: I-1].

La unión entre música y poesía es tan estrecha que consolida el término

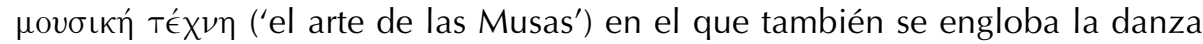
o la acción gestual. La expresión rítmico-melódica discurre paralela al texto verbal, formando una unidad indivisible. La música influye en la palabra, añadiéndole connotaciones; los versos influyen en la música condicionando la ejecución, con todos los matices desde el canto al recitado expresivo.

En uno de los pilares de la cultura de la Antigüedad, la mitología, que explica el origen y el devenir del mundo y de los hombres, también descubrimos la música como coartada. La música está presente en los mitos en diferentes aspectos: por un lado en la devoción practicada mediante el mito a los dioses, a través de la música; por otro lado, en la propia manifestación de los aspectos culturales que transmite el mito, afianzando los valores tradicionales y creando la memoria colectiva; y, además, permitiendo la repetición y trasmisión de los mismos a través de la mousiké, a lo que añadimos la repercusión que los mitos han tenido en el devenir histórico del resto de las artes.

El mito más significativo es el de Orfeo, cuyo arte es capaz de conmover a los mismos dioses. No solo el mito sobre el descenso al Hades explora el poder de la música sino que todas las manifestaciones en las que aparece Orfeo en la literatura, y en otras artes, forman un mito relacionado con la música. La literatura a través del mito de Orfeo expresa la relación de la música con la naturaleza (animales, plantas, rocas, mar, fenómenos metereológicos), el mundo humano (influencia en la expedición de los Argonautas, fue maestro de música), y el mundo de los dioses (sedujo a los dioses del Hades). La crítica literaria se ha detenido en el mito de Orfeo para considerarlo un mito de transgresión [Molina Moreno, 1988 y 1997; Bernabé, 2008: 73], significado para el que la literatura ha utilizado a la música, puesto que el protagonista intenta a través de esta atravesar las fronteras entre el hombre y la naturaleza o entre el hombre y los dioses. Un ejemplo claro de la música como coartada. 
La literatura mitológica se ve impregnada de la música, en un camino de ida y vuelta entre la literatura y la música, puesto que la literatura explica la mitología y los atributos musicales de los dioses, y las referencias musicales se llevarán a la vida cotidiana para el culto a esos mismos dioses. Entre las divinades, por ejemplo, se reconoce a protectores de la música, como las Musas, y se les relaciona con determinados instrumentos (aulos de Atenea, lyra de Hermes, siringa de Pan...).

Algunos mitos hacen referencia a los efectos del sonido en el ejecutante y en el público, como el olvido que provoca el canto de las sirenas (Odisea). Conocemos el cortejo de Dioniso, con instrumentos de viento y percusión de intensidad sonora usados en registros extremos, graves y agudos, con lo que era sencillo favorecer el frenesí dionisiaco, oponiéndose al carácter equilibrado que la mayoría de los mitos otorgó a la música. El cortejo de Dioniso, las Ménades y los Sátiros, es el encargado de tocar y cantar, como lo harán las Musas en el cortejo de Apolo. A Apolo se le relaciona con la música y la literatura. Según Hesíodo los aedos que se acompañan con la cítara son descendientes de Apolo y las Musas [Teogonía, 95]. Apolo era protector de la poesía y se le invocaba al comienzo de las composiciones poéticas. Apolo con su lira era protector de la poesía épica, que era impensable sin la música de la lira.

Los mitos vinculan la poesía con la música y son un testimonio de la función principal de esta última, en relación con la religión, la cosmogonía y la vida social. Teóricos como Pitágoras analizaron las relaciones numéricas y le atribuyeron cualidades éticas y mágicas, uniendo el concepto de mousiké con el principio ordenador del cosmos y los sentimientos del alma: la armonía de las esferas, el poder ascético de la música, etc. En este sentido, la unión de música y texto entronca con lo esencial de la cultura griega.

En Grecia los textos se compusieron para ser cantados con acompañamiento instrumental, sin embargo podemos señalar dos fases en las relaciones entre música y texto, siempre teniendo en cuenta que recogemos aquí tendencias generales: una con primacía del texto sobre la música y, otra, en la que la música cobró importancia por encima del texto (aunque en ningún momento estamos hablando de independencia total de ninguna de las dos). La primera fase, con el texto resaltado sobre la música, se organizó en nomoi ("leyes") para crear melodías que acompañaban a la parte literaria, la cual influía al mismo tiempo en la estructura musical ${ }^{2}$. Los géneros líricos tenían correspondencia entre el texto y la música: en

2. A lo que se añade la musicalidad del griego antiguo, que era una lengua modal y no tonal. No sólo la alternancia entre sílabas largas y breves sino también los diversos acentos (grave, agudo y circunflejo, que marcaban la modulación de la voz) hacían que incluso la lengua simplemente hablada diera una impresión "musical", de la que carecen nuestras lenguas modernas. La sucesión de sílabas largas y breves establecía la alternancia de tiempos fuertes y débiles. La relación doble entre la duración de la sílaba larga y la sílaba breve fue observada 
el epinicio, por ejemplo, las dos artes expresan un carácter triunfal, victorioso, creado por encargo y dedicado al vencedor de los juegos olímpicos. En la segunda fase, la época clásica, la música alcanzó cierta independencia del texto con desarrollos no ligados a este. Es la época de las harmoniai y del nuevo ditirambo de Timoteo de Mileto que dio al texto más expresividad, aunque con una música mimética que no dejó de lado el argumento literario. En Roma encontramos una situación que no difiere demasiado. La tragedia griega y el teatro posterior romano utilizaron la música magistralmente en relación con el texto (más adelante a la ópera, a la música de Wagner e incluso al cine, podríamos considerarlos como un renacimiento de esta tragedia). Así cobran auge el Corifeo y el Coro, que otorgan al canto solístico y coral tanta importancia como al diálogo y la acción escénica. Del coro se separó un primer actor diseñando una estructura dramática que ya fue fijada por Esquilo y Sófocles con las siguientes partes en la tragedia: prólogo, párodo (entrada del coro en escena), episodios recitados que condensan la acción, estásima (cantos corales intercalados entre los episodios) y éxodo (salida final del coro). Con Eurípides las relaciones música-literatura dieron un paso más y la música dejó de ser soporte melódico para pasar a connotar situaciones dramáticas, emociones y estados de ánimo. En sus creaciones podemos seguir la evolución de las relaciones música-literatura, desde que la música deja de ser soporte melódico del texto para pasar a connotarlo expresivamente, especialmente en las partes no estróficas, que quedan libres de la estructura de la misma. Como ha estudiado G. Comotti [1997: 31], "las monodias, raras y poco extensas en las tragedias del primer período, se hicieron cada vez más frecuentes y tuvieron mayor amplitud, configurando a la tragedia como un verdadero melodrama con arias y dúos". Así se enlazan texto y música en uno de los géneros más importantes en la Antigüedad.

El largo período de la Edad Media impulsó la parte musical; surgió la polifonía aunque también nos proporciona buenos ejemplos de monodia. En la parte polifónica destacamos las referencias del Códex Calistinus, Machaut o la Escuela de San Marcial de Limoges o Notre Dame; en la parte monódica los Carmina Burana, los goliardos y trovadores y, en su vertiente más religiosa, las misas responsoriales. En esta época el texto se unió a la música por ser su medio de expresión. La lírica popular fue muy rica y se basó en canciones que unen texto y música sin oscurecer el significado del primero, como en los villancicos con la estructura de estribillo y desarrollo, las canciones líricas como la jarcha con la rima determinada para el texto, los cancioneros, los romances, las cantigas, la lírica galaico-portuguesa... El Mester de Clerecía, sin embargo, fijó su atención en el texto que se estructuró con el ritmo de la cuaderna vía, aunque también pudo tener partes cantadas como suponemos en la obra de Berceo o el Libro de Buen

escrupulosamente en la ejecución del canto hasta la reforma musical de Timoteo (s. V-IV a.C.). A partir de él los compositores trataron con más libertad los elementos métricos, prolongando incluso hasta cinco tiempos la duración de la sílaba larga. 
Amor. El canto gregoriano también se decantó por la primacía del texto puesto que las sílabas influyeron en la construcción de la melodía. Se establecieron, por ejemplo, relaciones perfectas entre las cadencias del texto y la música, que era expresión y adorno del primero, aunque con la notación diastemática del gregoriano se va perdiendo el tratamiento de la relación del texto con la música.

En el Renacimiento, la parte literaria cobró especial interés. La función de la música fue extraer las ideas y afectos del texto y expresarlos en sonidos. En este sentido, Juan del Enzina ejemplifica el hecho de que la música debe velar porque el texto sea comprendido por el receptor [Armijo, 2005: 108]. Fue el primer escritor que introdujo la polifonía, mediante villancicos, en su obra, en las églogas, buscando un estilo musical apropiado para representar a los pastores. Es la época del Humanismo, que difundió la importancia de conocer música y literatura. También es la época en la que surgió un nuevo concepto de armonía a través del estudio de los acordes. En el teatro la música se integró, al igual que en la Antigüedad, como un elemento dramático más. Podríamos afirmar que el género dramático es el que nos revela desde más antiguo que ha asimilado para la escena la utilidad de música y texto, y que ha desarrollado unas pautas claras para la utilización de ambas; después las discusiones teóricas o prácticas girarán en torno a si usar texto y música de una manera u otra, por ejemplo en el s. XVIII si otorgar verosimilitud y no empañar la comprensión textual, pero la relación básica ya estaba fijada. En el caso renacentista, al que nos estamos refiriendo, encontramos el ejemplo de Gil Vicente, quien opta por las relaciones entre música y texto de analogía y complementariedad: la música duplicó de forma lírica la acción, mostró los sentimientos de los personajes, marcó entradas y salidas en el escenario, etc. También se une la música y la poesía en los madrigales, sobre textos elevados (poemas de Petrarca, por ejemplo), en los que la música no ensombreció la comprensión, hasta que esta rompió el equilibrio en la época barroca y buscó tensión y contraste. La importancia de la música sobre el texto en el Barroco es clara, aunque ambos se unieron para mostrar afectos. También en esta época la música en el género dramático fue esencial, como lo demuestran obras de Calderón, Tirso o Lope. En los intermedios musicales se utilizaron géneros menores como el baile, la jácara, la mojiganga... que en ocasiones son semejantes a un entremés cantado o bailado, puesto que se modificaron introduciendo a los personajes de la obra y escenificando las acciones narradas. Se perfeccionó la función de la música para crear ambiente, para atraer la atención del espectador, para ocultar el ruido de tramoyas (con instrumentos de sonido potente: chirimías, trompetas, cajas... en los cambios de escena) y para formar parte del desarrollo dramático, haciéndola indisociable de los versos, la acción y el escenario. Es el momento en el que surgió la ópera, un paso esencial en la unión entre literatura y música.

Por el contrario, el s. XVIII supuso un cambio estético y en las relaciones entre música y literatura se le otorgó primacía al texto, que permite la expresión racional por encima de los excesos barrocos. Esta es la propuesta que recogió 
Moratín, para quien la música debe buscar verosimilitud y realismo [Rodrigo Mancho, 2006:114-115]. También fue importante el texto en composiciones como los lied, pero la música no quedó atrás y se desplegó en la ópera y en oratorios y misas, que la utilizaron para mover los afectos, y en géneros populares como tonadillas o sainetes. El s. XIX situó a la música en el punto más alto y comenzó a ser valorada como un arte capaz de expresar aquello que no se puede expresar con palabras. El Romanticismo encontró en la música el prototipo de la expresión de la libertad e incluso de la verdad, que trascendía lo sensorial y creaba un lenguaje autónomo libre de la limitación de la palabra; exaltaciones que también se realizaron durante el s. XX. Composiciones de este período, como la música programática de los poemas sinfónicos, muestran un acercamiento desde la música hacia el texto. Surge el drama musical de la mano de Wagner, que aúna música y literatura (junto a otras artes) y utiliza la primera para los fines de la expresión dramática.

El cambio de siglo se produce entre las teorías evocadoras de Baudelaire o Mallarmé, entre otros, y los cambios de estética que desembocan en las vanguardias con gran riqueza expresiva tanto musical como literaria. La música es un recurso expresivo para la literatura, que alcanza así nuevos significados. La relación entre las dos artes es muy estrecha, como veremos más adelante.

Desde el s. XIX se han desdibujado las fronteras entre los espacios que han ocupado los creadores y los receptores tradicionalmente en el arte. El concepto de genio, atribuido al creador artístico, desplazó el interés hacia las singularidades del sujeto creador. El s. XX descubrió la importancia del sujeto receptor: más allá de la capacidad de otorgar sentido a la relación entre música y literatura (y a cualquier arte) su capacidad creadora, ya que puede otorgar a los objetos, a ciertos textos por ejemplo, categorías estéticas (así se recoge, por ejemplo, en los poemas de Cirlot y la música de su literatura). Hasta llegar al punto máximo de reivindicar el papel activo del receptor, a mediados del s. XX, para terminar el proceso creativo de la obra.

En definitiva, las relaciones entre música y literatura están presentes en el proceso artístico y expresivo de la cultura occidental, dando lugar a manifestaciones artísticas muy ricas y diversas. La primacía otorgada a la música o al texto ha ido variando a lo largo de los cambios en la estética; épocas como la renacentista y el s. XVII dan importancia al texto y otras, con el s. XIX a la cabeza, defienden la expresión musical por encima de la literatura. Una aproximación artística intensa y enriquecedora que sitúa el sentido de las relaciones entre música y literatura en las características culturales que las han creado.

Atendemos ahora a cuatro tipos de relaciones que podemos establecer entre música y texto y que, en definitiva, sirven para analizar el papel que se le otorga a la música desde la literatura. Los ejemplos propuestos simplemente son una muestra significativa de entre los muchos que podíamos haber elegido. Nos referimos a las relaciones de complementariedad, en las que música y texto se 
complementan mutuamente; a la evocación de la música desde el texto, considerada como tema u objeto; a las relaciones de intertextualidad entre las dos artes; y a los casos en los que se establecen relaciones de semejanza porque las composiciones dan respuesta a una misma estética.

\section{Relaciones de complementariedad entre música y literatura}

La música, en este caso, es coartada de la literatura porque sirve para complementarla. Es el tipo de relación más abundante que se establece entre música y texto, simplemente utilizando la música como acompañamiento, con más independencia cuanto mayor virtuosismo tenga la parte musical, o mediante una música mimética, apoyando el significado del texto. Los ejemplos son muy numerosos (desde las canciones populares al género operístico). Lo que se expresa mediante un arte se complementa con el otro, enriqueciendo los matices expresivos y la significación.

Entre las numerosas composiciones que mantienen este tipo de relación, elegimos el madrigal Cruda Amarilli de Monteverdi porque supuso el cambio de la estética renacentista a la barroca. Sobre un poema pastoril, I/ pastor fido de Guarini, se relaciona música y texto de manera magistral para expresar el amor del poeta no correspondido. Los lamentos amargos y de desesperación (“iCruda Amarilli!") se expresan con repeticiones y tesitura aguda, lo que enriquece la expresión con un claro gesto teatral que más adelante reconoceremos en las óperas. Las palabras que se refieren a la belleza de la dama, "más pálida y más bella que el blanco jazmín", carecen de sonidos graves que las oscurezcan. El contraste entre el tutti y el unísono se utiliza para el vocativo "Amarilli". El momento contrapuntístico se reserva para el movimiento sinuoso de la serpiente, con la aliteración del sonido $s$. Y, en general, la declamación musical se adecua al ritmo y la acentuación del texto. Las relaciones de complementariedad entre texto y música están en la base de la teoría barroca de los afectos, que identifica el registro grave y la inmovilidad melódica, por ejemplo, con los conceptos negativos (así lo encontramos en Nigra Sum, de Monteverdi).

Los diferentes elementos expresivos de las dos artes se unen en la formulación de ideas afines con diferentes lenguajes.

\section{La evocación de la música: la música como objeto}

Nos referimos a las obras literarias cuya coartada no es introducir la música sino hablar sobre ella. Aparecen en todas las épocas, pero también en el sentido inverso: obras musicales que buscan la complicidad de la literatura.

Elegimos como muestra las referencias del escritor L. Fernández de Moratín, quien Ilevó a escena el discurso didáctico del s. XVIII, y en quien no esperábamos encontrar una postura clara en defensa de la utilización de la música ligada a la expresión del texto ni la presencia, en sus diálogos, de géneros populares 
musicales de moda en la época, sobre todo porque mostró reparos al teatro musical. Llevó al teatro la vida cotidiana de la burguesía de su tiempo, bajo las máximas de realismo y verosimilitud, que aplicó también a la música, velando porque no interrumpiera la transmisión del contenido textual. No desdeñó el uso musical, que utilizó al comienzo de las obras, en intermedios, en ocasiones en las que era requerida, pero no abusa de ella ni hace que la atención del espectador se desvíe de ella.

En El sí de las niñas, el eje que vertebra la obra es una relación de pareja, que aparece reiterada por su repetición con personajes diferentes, Don Diego con Doña Francisca y esta con Don Carlos (o Don Félix), y que puede asemejarse a la reiteración melódica de la contradanza, género musical del que hablan los personajes, ritmo compuesto a grandes rasgos por varias secciones de ocho compases que se repiten. "Si no ensayamos bien esta contradanza, nos hemos de perder en ella" [Acto I, escena IX], dice Rita, con una reflexión que también puede referirse al desarrollo argumental.

En La comedia nueva o El café las referencias se dirigen a la tonadilla valorando la construcción de la parte musical y de la literaria:

D. ELEUTERIO: Si se lo he dicho a usted ya. La tonadilla que han puesto a mi función no vale nada, la van a silbar, y quiero concluir esta mía para que la canten mañana.

D. SERAPIO: ¿Mañana? ¿Conque mañana se ha de cantar, y aún no están hechas ni letra ni música?

D. ELEUTERIO: Y aun esta tarde pudieran cantarla, si usted me apura. ¿Qué dificultad? Ocho o diez versos de introducción, diciendo que callen y atiendan, y chitito. Después unas cuantas coplillas del mercader que hurta, el peluquero que lleva papeles, la niña que está opilada, el cadete que se baldó en el portal; cuatro equivoquillos, etc., y luego se concluye con seguidillas de la tempestad, el canario, la pastorcilla y el arroyito. La música ya se sabe cuál ha de ser: la que se pone en todas; se añade o se quita un par de gorgoritos, y estamos al cabo de la calle. (Acto I, Escena III).

En El viaje a Italia, criticó que la música tiraniza al texto cuando los intérpretes comienzan da capo los pasajes musicales de más éxito, perdiendo el sentido de la obra ${ }^{3}$. Vemos en estos ejemplos cómo la música es el objeto del que se ocupa el texto.

3. "Toda la ilusión teatral desaparece al ponerse en marcha la potente maquinaria orquestal: los preludios instrumentales enfrían el progreso de la acción, el canto expresa con lentitud los afectos más vehementes de las pasiones humanas y los ingeniosos movimientos musicales parecen reñidos con la sobriedad, el vigor y la sencillez propios de la agitación del ánimo." [Rodrigo Mancho, 2006: 114-115]. 
Otro ejemplo significativo de un poeta que evoca la música en su texto, que convierte a la música en el objeto de lo que escribe, es el modernista Rubén Darío. Afirmó que su creación respondía "al divino imperio de la música; música de las ideas, música del verbo". Busca el efecto musical para evocaciones esplendorosas, brillantes ("las trompas guerreras resuenan" o "saludan con voces de bronce las trompas de guerra que tocan marcha / triunfal" de Marcha triunfal) y para la expresión más delicada e íntima ("iban frases vagas y tenues suspiros / entre los sollozos de los violonchelos" de Era un aire suave; o "sonora, argentina, fresca, / la victoria de tu risa / funambulesca" de Canción de Carnaval). Se acerca a la música utilizando diferentes recursos literarios: fónicos, como aliteraciones ("bajo el ala aleve del leve abanico" de Era un aire suave o "Ínclitas razas ubérrimas, sangre de Hispania profunda" de Salutación del optimista), sinestesias sugerentes por la mezcla de sensaciones relacionadas con significados musicales ("sones alados", "sol sonoro", "arpegios áureos"...), léxico referido a bailes o composiciones musicales ("pavanas", "gavotas", y también en los títulos: El canto errante, Canción de otoño en primavera, Marcha triunfal...), oposiciones de palabras con la música como base ("está mudo el teclado de su clave sonoro" de Sonatina), etc.

Junto a la literatura que tiene a la música como objeto, discurre el camino inverso: la música cuyo objeto es la literatura. Es el caso, entre otros, de las sinfonías y poemas sinfónicos del s. XIX donde la música describe paisajes románticos, incluso con alusiones geográficas (Italiana de Mendelsshon). Berlioz consigue con su Sinfonía Fantástica una revolución estética por el uso integral de un poema literario. Los cinco movimientos que la forman recogen en el léxico rasgos románticos de la literatura ("Ensueños y pasiones", "La marcha ante el cadalso", etc.).

\section{Intertextualidad entre música y literatura}

Al hablar de intertextualidad entre las dos artes nos referimos a la literatura que recoge rasgos musicales. En este sentido, la música es su coartada. El movimiento estético más propicio para este tipo de relación entre música y texto es el Romanticismo, aunque no es exclusivo. Si la música es la más romántica de las artes y la poesía es la que tiene más consideración dentro de las que usan la palabra por su subjetividad, intimismo y poder de evocación, ambas artes se unen en las composiciones que incluso se refieren a la música en el título. La distribución de acentos, el ritmo y la estructura con alternancia de estrofas más estribillo adoptan rasgos musicales. En La canción del pirata representa un paisaje romántico: noche, luna, viento, tempestad, exotismo... Exalta la libertad individual romántica al igual que en La canción del mendigo. Las influencias de las Canciones de Espronceda las encontramos en V. Hugo o Byron (mayor armonía y lirismo en Espronceda; mayor profundidad de pensamiento y fuerza narrativa en Byron). 
La estructura cuidada de las canciones y de otras obras de Espronceda las acerca a efectos musicales: en El canto del cosaco aparecen diez partes iguales con tres estrofas cada una de ellas; en La canción del pirata, una presentación y cinco partes iguales con estribillo; La canción del verdugo es un continuo polimétrico; en El reo de muerte, dos partes explícitamente señaladas, con polimetría, cuyas variaciones se adecuan al tono del pasaje; en El mendigo, cuatro partes iguales de tres estrofas más estribillo; en El diablo mundo, una introducción y seis cantos, con la utilización de coros, etc.

En El estudiante de Salamanca, con mil cuatrocientos versos, muestra en su conjunto un crescendo comparable con el musical: cuatro partes desiguales que van de menos a más hasta el final. Métricamente los efectos sonoros conseguidos son diferentes y variados según aparezcan romances, octavillas, octavas reales, redondillas, décimas... La descripción del espacio nos recuerda a la que aparecía, por ejemplo, en sinfonías: Salamanca de noche, Ilena de fantasmas, voces temorosas, muertos que dejan la tumba, aullidos de perros; después de la presentación de los protagonistas volvemos a la noche pero ahora primaveral, la del amor y la del recuerdo en la que Elvira Ilora su desengaño; transformación, más adelante, de la ciudad en una ciudad extraña y desconocida, con clima mitad verdad y mitad sueño, que indica que la acción se ha interiorizado, ha pasado a la conciencia del protagonista. Es el final: Montemar, en un deambular nocturno y sonámbulo, contempla su propio entierro y llega detrás de la dama a la mansión de los muertos; D. Félix arremete contra los espectros en una lucha desesperada contra el miedo. Es una correlación perfecta: Espronceda une la vida que se extingue, la llama que se apaga y el verso que se reduce al mínimo silábico en el gran clímax de la obra, rasgos que también expresa la música del período.

Las relaciones de intertextualidad entre música y literatura también las encontramos en otras épocas, menos predecibles en este aspecto que el Romanticismo. En J. E. Cirlot, poeta de mediados del s. XX, descubrimos cómo la música tiene cabida en sus versos. Como músico perteneció al Círculo Manuel de Falla de Barcelona, que dinamizó la vida musical de la ciudad y se acercó a la música postimpresionista francesa y a Hindemith, Stravinsky y Schönberg. Cirlot rindió homenaje a estos músicos en alguno de sus poemas (Oda a Igor Stravinsky, por ejemplo, o el estudio Igor Stravinsky. Su tiempo, su significación, su obra).

Su primera obra poética es el ballet La muerte de Gerión, que integra música, color y movimiento con poesía surrealista. Los colores de cada escena siguen el teclado de luces de Scriabin, otorgándoles así un valor sinestésico. Scriabin superó la tonalidad mediante centros sonoros, creando el "acorde místico" con Do-Fa sostenido-Si bemol-Mi-La-Re, que se basa en el intervalo de cuarta y que aparece en Prometeo. Son acordes que se organizan en secuencias que transmiten sensaciones estáticas. Algunos poemas de Cirlot traspasan estos centros de sonido a centros léxicos en el texto, que van generando sus propias estructuras sintácticas, como El salmo de la batalla, estructurado en torno a las estructuras "Ha llegado 
la hora de + Sintagma Nominal" y "Oh + Sintagma Nominal + nexo + Sintagma Nominal", con una estructura circular del poema que le otorga estatismo.

Los poemas de Cirlot reflejan rasgos de la música coetánea, como en Bronwyn, permutaciones, donde emplea la combinación de versos y palabras: trece poemas con variaciones progresivas, primero permutando el orden de los versos (II y III) y después de las palabras (IV y V), para seguir con cambios totales con métrica regular (VI y VII) y no regular (VIII y XI), depurando el texto en los últimos cinco poemas de manera que se hace más breve. Las diferencias se establecen respecto al poema I, el modelo, además con doce versos como si fuera la serie musical del dodecafonismo. La técnica ya la había utilizado en una obra anterior, Homenaje a Bécquer, creando once poemas breves con elementos del poema Volverán las oscuras golondrinas sin un orden reconocible.

En este sentido la música estructura y genera temas y formas poéticas. Cirlot encontró nuevas posibilidades para la poesía en la música, extremando la unión entre ambas que llegó a condicionar todos los aspectos poéticos: el léxico, la estructura, la sonoridad, etc.

Pero no siempre la intertextualidad se da de forma tan clara. Muchas veces la literatura evoca referencias musicales que luego no llegan a plasmarse en el texto. Es el caso de Valle-Inclán, que titula a su obra Sonatas aunque la estructura de las mismas no se corresponde con la forma musical. Algunos elementos del léxico le dan musicalidad: ritmo, estructuras paralelísticas, referencias a sonidos, etc. ("El rumor de sus voces se perdía en los rumores de la tarde", en Sonata de primavera). Semántica y fonológicamente la obra transmite sensaciones de sonidos y emociones que también otorgan al texto su propio ritmo. Las Sonatas son fragmentos evocadores en los que no importa tanto la unidad como la contemplación de escenas. En este sentido es acertado el título musical, aunque no encontramos que influya especialmente en el texto, que tiende a la musicalidad respondiendo a los cánones modernistas, con los que se relaciona el título musical, pero no con su forma específica. Los temas, situaciones, personajes recurrentes, tienen que ver más con la idea de Valle-Inclán de la palpitación que engendra círculos infinitos y que produce la idea de quietud y de eterno devenir, que recoge en La lámpara maravillosa.

Aunque podemos pensar que es más sencilla la intertextualidad de la música en el género poético que en el narrativo, también la encontramos en novelas. Nos sirve como ejemplo El invierno en Lisboa, de A. Muñoz Molina. Destacan en la novela la particular organización temporal de los hechos, presentados en una línea cronológica fragmentada y discontinua llena de retrospecciones y anticipaciones, su focalización a través de personajes y la presencia de otras artes, especialmente la música y el cine (este en la segunda mitad de la novela), que no simplemente son acompañantes de lo relatado en la fábula sino que forman parte de la estructura de la misma, a lo que se añade la pintura aunque esta sin relevancia estructural. 
La música está presente a lo largo de toda la obra ya que la trama se centra en la vida de un pianista de jazz, lo cual da pie a reflexiones sobre el significado de la música, su carga emocional, la forma de tocar, etc. Pero además, la música crea la trama estableciendo relaciones entre el tiempo pasado y el presente.

El protagonista, Santiago Biralbo, toca en el Giacomo Dolphin Trio, un trío de música jazz con gran éxito por su música como conjunto, un buen empaste entre los instrumentos y por las improvisaciones. La estructura de este trío, y su relación como grupo de jazz y como improvisadores individuales sobre la base instrumental del resto, se traspasa a la estructura de la novela. En este sentido descubrimos cómo la novela se articula en torno a tríos que en ocasiones se unen, como el conjunto de jazz, y en ocasiones destaca, como si fueran instrumentistas, su particular improvisación individual, pero siempre sobre la base de los otros componentes del trío que están pendientes de las improvisaciones para adecuar su música. Así se nos presentan los principales personajes: el trío formado por Biralbo (el pianista de jazz), Lucrecia (el amor que persigue) y un tercer personaje que va cambiando según la trama. Los personajes se describen por sus reacciones al tocar o escuchar el jazz. Y también, como el trío de jazz, va surgiendo la vida que el protagonista ha tenido en tres ciudades: San Sebastián, Madrid y Lisboa. Las referencias al jazz son las referencias al amor. El silencio, los escasos capítulos en los que la música no aparece, representa la relación rota entre Lucrecia y Malcolm. La música de jazz se convierte en el eje de la trama y de la forma de contar.

\section{Relaciones de semejanza entre música y literatura: una misma estética}

Las relaciones de semejanza, en las que la obra musical y la literaria, cada una con los códigos que le son propios, coinciden porque dan respuesta a una misma necesidad estética son realmente sugerentes. Sin embargo, creemos que no aportan demasiado al analizar la coartada que supone la música para la literatura, puesto que en el momento en que se relacionen los dos códigos estaríamos en uno de los casos anteriores: complementariedad, la música como objeto o intertextualidad entre las dos artes.

Aun así, queremos señalar que en este tipo de relaciones destacan las composiciones del s. XX, profuso en la creación de tendencias y movimientos estéticos, que tuvieron repercusión en las dos artes dando respuesta a una misma estética desde dos códigos diferentes. Si realizamos un análisis comparativo descubrimos asociaciones novedosas entre movimientos literarios y musicales, en los que no nos detenemos porque superan los límites de este trabajo: el Impresionismo musical coincide en algunos aspectos con el Modernismo literario, pues manifiestan la preferencia por el detalle, la sensualidad, la sugerencia y la creación de impresiones en el receptor; el Nacionalismo musical, con la Generación del 98, ambos preocupados por el país: los primeros con el estudio etnomusicológico y la música nacional y, los segundos, con el paisaje castellano y los problemas de España; las vanguardias son movimentos envolventes 
que agrupan a todas las artes, por lo que facilitan la unión entre música y literatura, que utilizan recursos equiparables: acordes disonantes junto a símbolos o metáforas disociadas de su elemento real, por ejemplo; el Neoclasicismo musical, con la novela social de los años 50; la búsqueda de nuevos lenguajes en la segunda mitad del siglo: serialismo, música aleatoria, indeterminismo, etc., junto a la literatura del movimiento pánico franco-español, el experimentalismo con cambios en la perspectiva, la focalización, la puntuación, etc. La primera década del s. XXI no ha mantenido reglas fijas en los procesos creativos musicales y literarios, sino que muestra la apertura a todas las tendencias, tanto a las que siguen los rasgos más clásicos como a los procedimientos que en su día fueron más vanguardistas, todos ellos útiles para expresar la complejidad del mundo contemporáneo.

\section{La música como coartada de la literatura}

La música ha sido la coartada de la literatura desde los primeros testimonios de la cultura occidental hasta nuestros días, más allá de las exposiciones teóricas que tratan la importancia de la música sobre el texto o de este sobre la música, y más allá de los breves ejemplos puntuales a los que hemos hecho referencia en este artículo, que no llegan a ser una muestra significativa de la riqueza de las composiciones a lo largo de la historia. No nos referimos solo a la literatura no ficcional, con ensayos o tratados teóricos sobre la relación que se establece entre ambas, sino a la propia literatura de ficción en sus tres géneros: lírico, dramático y narrativo. Creemos que la música entra así a formar parte de lo que Wittgenstein Ilamaba "el embrujo del lenguaje" [1999:30], puesto que refuerza, añade, restringe connotaciones a la riqueza de significados que ya han sido expresados mediante el texto. La música ha hechizado a la literatura, y esta se ha dejado hechizar por aquella, porque ambas tienen una similitud mucho más profunda que la evidente diferencia formal; no en vano, el discurso textual se construye a través de la interrelación de palabras y silencios.

La música es una coartada para el género lírico, no solo acompaña al texto sino que llega a influir en su estructura. Gran parte de la literarura de tradición oral no puede entenderse sin la música: ha otorgado a los textos un carácter social con funciones dentro de la colectividad (canciones para diferentes oficios, fiestas populares, historias legendarias de determinados lugares...); además de reforzar el carácter expresivo del texto puede añadir matices que no se pueden conseguir con las palabras; también contribuye a la permanencia de los textos, con más variantes cuanto mayor sea la difusión, y a su divulgación; etc. Así lo vemos en romances cantados o canciones populares pero también en la música sacra, donde los textos se musicalizan para mover a la devoción de los fieles y alcanzar un grado mayor de abstracción y espiritualidad. La música incide y condiciona el texto: versos que se adecuan a las líneas melódicas, distribución diferente de metros en estrofas y estribillos, versos que se adaptan a las modulaciones que marcan el cierre musical, etc. 
El género dramático establece diferentes coartadas con la música, desde hacer uso de ella simplemente como música incidental, aportando verosimilitud, hasta utilizar la música para acentuar las emociones personales, la acción (reforzando lo representado, adelantando acontecimientos...), etc. Incluso la música puede entrar a formar parte de la estructura de la obra, marcando el final de los actos o creando espectáculos exclusivos, como puede ser el Fin de Fiesta al final de la representación teatral. También puede tener influencia argumental, como ocurre en cierto tipo de teatro: la tragedia griega, por ejemplo, a través de los papeles de Coro y Corifeo, o cronológicamente en el punto opuesto, en el teatro experimental de finales del s. XX (con compañías como Els Comediants o Els Joglars), donde la música, junto a otros elementos visuales y experimentales, constituye el eje de la obra.

En ocasiones, la música se evoca y no "suena". Quizá esta sea la mayor coartada de la música con la literatura, consiguiendo hacerla presente cuando "no está". Es lo que ocurre en el género narrativo, generalmente enfocado a la lectura individual y silenciosa, pero que puede traer la música a su texto y hablar sobre ella e introducirla en su desarrollo. Lo mismo ocurre cuando en el teatro los personajes reflexionan sobre la música (como hace Moratín sobre la música coetánea) o la lírica imita a la música aunque el texto no va a ser musicalizado (poemas de Darío o Espronceda). No siempre las relaciones son claras sino que a veces se utiliza a la música por su capacidad para sugerir, para evocar realidades y estados de ánimo o por las referencias culturales que representa. Así, podemos encontrar obras como las Sonatas de Valle-Inclán, donde un texto que responde a una estética modernista sugerente no sigue ninguna estructura clara que se identifique con el título; es la evocación a la música sin apuntar a ningún contenido.

El hecho de que ciertos escritores sean músicos facilita la influencia del arte musical en el literario, especialmente en la estructura de la obra, quizá el aspecto más díficil de conseguir. Es el caso, por ejemplo, de Gil Vicente en el teatro renacentista o Lorca o Cirlot en la poesía del s. XX. Pero el hechizo que la música ejerce sobre la literatura es tan grande que no se reduce a estos supuestos.

Por ello, la búsqueda de la musicalidad por parte de la literatura ha sido una constante a lo largo de la historia de la cultura. El género lírico ha sido el más propicio, puesto que el ritmo y la musicalidad forman parte de su esencia. Pero la música está presente, o evocada, en el resto de géneros literarios, es su coartada.

\section{Bibliografía}

ADORNO, T., "Música, lenguaje y su relación en la composición actual", en Sobre la Música, Barcelona, Paidós, 2000, pp. 25-39.

ARMIJO, C. E., "Música, poesía y corte: el mundo de Juan del Encina", en Edad de oro cantabrigense, Actas VII Congreso de la Asociación Internacional de Hispanistas del Siglo de Oro, Madrid, AISO, 2006, pp. 103-108. 
BERNABÉ, A., "Viajes de Orfeo", en A. Bernabé y F. Casadesús (coords.), Orfeo y la tradición órfica. Un reencuentro, vol. I, Madrid, Akal, 2008, pp. 59-74.

CATTIN, G., Historia de la música, II. El Medioevo. Primera parte, Madrid, Turner, 1987.

COMOTTI, G., Historia de la Música I. La música en la cultura griega y romana, Madrid, Turner, 1986 (1977).

CORTÁZAR, J., Rayuela, Barcelona, Editorial Sudamericana, 1995.

DARÍO, R., Obras Completas, Madrid, Mundo Latino, 1917.

ECO, U., La estructura ausente. Introducción a la semiótica, Barcelona, Lumen, 1968.

ENZINA, J., Romances y villancicos, grabación de Hespèrion XX, Astrée Auvidis, 1993.

FERNÁNDEZ DE MORATÍN, L., La comedia nueva. El sí de las niñas, edición de J. Dowling y R. Andioc, Madrid, Castalia, 1993.

FERNANDO NúÑEZ, D., "La voluntad de estilo en Rubén Darío", Halogramática literaria, $\mathrm{n}^{\mathrm{O}}$ 2, VI, 2006.

GALLICO, C., Historia de la música 4. La época del Humanismo y del Renacimiento, Madrid, Turner Música, 1986.

GROUT, D. J. y C. V. PALISCA, Historia de la música occidental, I y II, Edición revisada y ampliada, Madrid, Alianza, 1997 (1984).

HESÍODO, Obras y fragmentos, edición de A. Pérez Jiménez y A. Martínez, Madrid, Gredos, 1990.

HOMERO, Ilíada, Madrid, Gredos, 2006 (1982).

JAKOBSON, R., "Lingüística y poética", en Ensayos de Lingüística General, Barcelona, Seix Barral, 1981.

LEDE, E., "Cruda Amarilli. (Quinto libro de madrigales de Monteverdi)", Revista de divulgación musical Relafare, 2007. www.relafare.eu (última consulta, diciembre 2012)

LEÓN TELLO, F. J., La Teoría española de la música en los siglos XVII y XVIII, Madrid, Instituto Español de Musicología, CSIC, 1973.

MANJÓN-CABEZA, D. y T. SCHMITT, "Mi voz en el sonido de tu luz. Estructuras musicales en la poesía de Juan-Eduardo Cirlot", Bulletin of Spanish Studies, v. 83, no 4, 2006, pp. 523-539.

MOLINA MORENO, F., "Quinteto para dioses músicos en la mitología griega", Estudios Clásicos, Tomo 40, no 113, 1988, pp. 7-36.

—, "Orfeo músico", Cuadernos de Filología Clásica: Estudios Griegos e Indoeuropeos, no 7, 1997, pp. 287-308.

MUÑOZ MOLINA, A., El invierno en Lisboa, Barcelona, Seix Barral, 1993.

PALACIOS, A., "Juan Eduardo Cirlot y la música", Jugar con fuego. Grave e maestoso, no 2, 2011. 
REED, T. P., "Tócalo otra vez, Santiago. Mass Culture, Memory and Identity in Antonio Muñoz Molina's El invierno en Lisboa", Letras Hispánicas, vol. 1, nº 1, 2004, pp. 18-36.

RODRIGO MANCHO, R., "Apuntaciones teatrales de Leandro Fernández de Moratín en su Viaje a Italia", en I. Romera Pintor y J. L. Sirera (ed.), Relación entre los teatros español e italiano. Siglos XVI a XX, Valencia, Universidad de Valencia, 2006, pp. 105-126.

VALLE-INCLÁN, R. M., Sonata de Otoño. Sonata de Invierno. Sonata de Primavera. Sonata de Estío, Madrid, Narrativa Austral, 2011.

WALTER HILL, J., La música barroca, Madrid, Akal, 2008.

WITTGENSTEIN, L., Investigaciones filosóficas, Barcelona, Altaya, 1999. 